\title{
Response of Paddy Straw Mulching and Farmyard Manure in Colocasia under Jhum Fields in Zunheboto District of Nagaland
}

\section{Sentimenla}

Subject Matter Specialist (Soil Science), KVK, Nagaland University, Lumami, Nagaland, India

*Corresponding author: sentijamir2009@gmail.com (ORCID ID: 0000-0003-0217-8710)

Paper No. 933

Received: 14-06-2021

Revised: 25-07-2021

Accepted: 29-08-2021

\begin{abstract}
Farm Trials were conducted in the jhum fields of Zunheboto district under rainfed conditions to observe the Effect Of Paddy Straw Mulching and FYM in Colocasia crop. Three jhum fields of Lumami village were selected for each one-hectare area. Colocasia being an essential crop of this area, was selected for the trial. It was observed that the use of Paddy Straw Mulching @ 12t ha ${ }^{-1}$ at $3 \mathrm{~cm}$ thickness and FYM@ $10 \mathrm{t} \mathrm{ha}^{-1}$ increased the soil moisture and reduced the soil temperature as compared to the farmers' practice. The mean temperature at 15,30 , and $45 \mathrm{DAP}$ in the trial plot ranged from $26.2,30.3$ to $31.7^{\circ} \mathrm{C}$ and mean soil moisture at $45 \mathrm{DAP}$ from $5 \mathrm{~cm}$ depth was $28.9 \%$ as compared to the farmers practice were the mean temperature was higher, ranging from $27.0,32.3$ and $32.5^{\circ} \mathrm{C}$ and mean moisture of $22.2 \%$ where paddy straw mulching was not used. The mean yield, net income, and B:C ratio were also increased to $3030 \mathrm{~kg}$ $\mathrm{ha}^{-1}, ₹ 1,01033$, and 3.00 over farmers practice of $2292 \mathrm{~kg} \mathrm{ha}^{-1}, ₹ 64,100$, and 2.27 .

\section{HIGHLIGHTS}

( Application of paddy straw @ $12 \mathrm{t} \mathrm{ha}^{-1}$ at $3 \mathrm{~cm}$ thickness and FYM@ $10 \mathrm{t} \mathrm{ha} \mathrm{a}^{-1}$ in colocasia crop have decreased the soil temperature and increased the soil moisture in the jhum fields.

0 The yield, net income, and B:C ratio were also enhanced.

( The soil fertility status was also improved.
\end{abstract}

Keywords: B:C ratio, Colocasia, FYM, Mulching, Paddy straw

Colocasia or taro (Colocasia esculanta L.) is an important tuber crop widely grown worldwide. India is one of the center origins where it is grown in a wide range of soils with $\mathrm{pH}$ ranging from 5.5 to 7 between $21 .-27^{\circ} \mathrm{C}$ temperature. It is rich in vitamins, minerals and is a rich source of protein and dietary fiber (Temesgen 2015). It contents starch $(70-80 \mathrm{~g} / 100 \mathrm{~g}$ dry taro), fiber $(0.8 \%)$, ash $(1.2 \%)$, fat $(0.2 \%)$ and protein $(1.5 \%)$ (Rashmi et al. 2018). In India, about $48 \%$ of the food crops and $68 \%$ of non-food crops areas are under rainfed, where farming is practiced in a wide-range of agro-climatic conditions, soil type, and rainfall

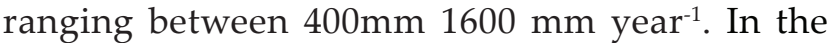
North-Eastern region of India, it is cultivated on a large scale because of its nutritional quality and as a means of income generation (Buragohain et al. 2013). The corms, cornel, and leaves are the edible part of the plant. In Nagaland, it is cultivated under rainfed conditions, and it is considered an important crop next to rice (Mezhii et al. 2017). Being a rainfed crop, it is prone to poor growth or crop failure due to insufficient moisture. Moisture conservation becomes an important practice to provide sufficient moisture and enhance the growth

How to cite this article: Sentimenla. 2021. Response of Paddy Straw Mulching and Farmyard Manure in Colocasia under Jhum Fields in Zunheboto District of Nagaland. IJAEB, 14(03): 469-473.

Source of Support: None; Conflict of Interest: None (क) 
and yield of the crop under rainfed conditions. Mulching is a technique of covering the surface soil to reduce water loss and improve moisture retention, maintain soil temperature, control soil erosion and weed growth (Yang et al. 2003). The use of organic mulch like paddy straw helps in moisture conservation and adds nutrients into the soil under rainfed cultivation (Chakraborty et al. 2008). The use of paddy straw as mulch also adds $6 \mathrm{~g}$ of nitrogen and $0.8 \mathrm{~g}$ of phosphorus per $\mathrm{kg}$ of paddy straw. It improves the soil's physical, chemical, and biological properties such as $\mathrm{pH}$, organic carbon, water holding capacity, bulk density and prevents the leaching of nitrates over a period (Kumar et al. 2014). Almost all the areas under shifting cultivation in Nagaland are rainfed, where Zunheboto district accounts for 23.29 thousand ha area where colocasia crop occupies 0.20 thousand hectares (Anonymous, 2018). However, its productivity per hectare is less. The average rainfall in the district is about $200 \mathrm{~cm}$ and receives heavy rainfall from July to August but due to climatic changes, the rainfall pattern is often affected, resulting in low productivity of the crop. Considering straw mulching as an important technique to maintain soil temperature, soil moisture, soil conservation, and adds nutrients into the soil, this trial on paddy straw mulching in colocasia was undertaken in Lumami village under Zunheboto district to assess the Soil temperature, soil moisture, yield, economics and soil fertility status of the soil. The observations were then compared with the farmer's practice where paddy straw mulching was not applied.

\section{MATERIALS AND METHODS}

An -farm trial was conducted at three locations under Lumami village covering 1 ha each of jhum fields under the Zunheboto district of Nagaland during 2018-19. For this trial, three locations were selected under jhum fields. Materials used were local variety colocasia @ 800 $\mathrm{kg} \mathrm{ha}^{-1}$, paddy straw mulching@12t ha-1 at $3 \mathrm{~cm}$ thickness, and FYM@ 10t $\mathrm{ha}^{-1}$ and irrigation at 1-week interval. The soil status of the fields was $\mathrm{pH}$ ranging from 5.5 to $6.5,0.30$ to $0.55 \%$ organic carbon, 235 to $245 \mathrm{~kg} \mathrm{ha}^{-1}$ available nitrogen, 17.50 to $18.32 \mathrm{~kg} \mathrm{ha}^{-1}$ available phosphorus, and $135-159 \mathrm{~kg} \mathrm{ha}^{-1}$ of available potassium. The crop was sown in the month of May 2018 and harvested in October. Parameters such as soil temperature were measured at $0-5 \mathrm{~cm}$ depth @15, 30, and 45 days after planting, soil moisture at 45 days after planting where irrigation was done at one week intervals, yield, B:C ratio, and soil fertility status of the soils after harvest were recorded. The soil temperature, soil moisture, available soil nitrogen, phosphorus, and potassium were analyzed using soil thermometer, Gravimetric method, alkaline $\mathrm{KMnO}_{4}$ distillation method (Subbiah and Asija 1956), Bray's No. 1 method (Bray and Kurtz 1945), flame photometer (Jackson 1973). The soil moisture content was determined by digging out soils with the help of an auger from $5 \mathrm{~cm}$ depth in the field. The fresh soil is weighed, and then oven-dried at $105^{\circ} \mathrm{C}$ for 24 hours. The soil moisture content is then measured using fresh soil samples and oven-dried soil samples by using the formula:

Soil moisture content $=$

$$
\frac{\text { Fresh weight soil }(\mathrm{g})-\text { Dry weight soil }(\mathrm{g})}{\text { Dry weight soil }(\mathrm{g})} \times 100
$$

\section{RESULTS AND DISCUSSION}

The results shown in table 1 indicate that the soil temperature is reduced and the soil moisture is increased in the trial plots of jhum fields with paddy straw mulch@ $12 \mathrm{t} \mathrm{ha}^{-1}$ at $3 \mathrm{~cm}$ thickness and FYM@ $10 \mathrm{t} \mathrm{ha}^{-1}$ as compared to the farmers' practice. The mean temperature at 15, 30 and $45 \mathrm{DAP}$ in the trial plot ranged from $26.2,30.3$ to $31.7{ }^{\circ} \mathrm{C}$. The mean soil moisture at $45 \mathrm{DAP}$ was $28.9 \%$ as compared to the farmers' practice, where mean temperature was higher, ranging from $27.0,32.3$ and $32.5^{\circ} \mathrm{C}$ and mean moisture of $22.2 \%$. Suminarti et al. (2020) reported suppression of the maximum soil temperature of $4.41,5.17,5.07$ and an increase in soil moisture by $4.9^{\circ} \mathrm{C}$ using $10 \mathrm{~cm}$ mulch length and 2, 4, 6 and $8 \mathrm{~cm}$ thickness of paddy straw mulch in beetroot. Mulching also helps insulate the soil by providing a buffer for soil temperatures (Kader et al. 2019). Miyasaka et al. (2001) also reported an increased in soil moisture content due to paddy straw mulching in taro crops under rainfed conditions. This is because of the soil moisture being conserved in the soil through mulching which creates a microclimatic soil condition, controls weeds, reduces evaporation, and increases infiltration of water (Yang et al. 2003). Through mulch decomposition and humus formation, soil water holding capacity can also be 
Table 1: Effect of paddy straw mulching on soil temperature and soil moisture of colocasia crop

\begin{tabular}{|c|c|c|c|c|c|c|c|c|}
\hline \multirow{3}{*}{ Location } & \multicolumn{6}{|c|}{ Soil temperature $\left({ }^{\circ} \mathrm{C}\right)$} & \multirow{2}{*}{\multicolumn{2}{|c|}{$\begin{array}{l}\text { Soil moisture }(\%) \\
\text { (At } 45 \text { DAP) }\end{array}$}} \\
\hline & \multicolumn{2}{|c|}{15 DAP } & \multicolumn{2}{|c|}{30 DAP } & \multicolumn{2}{|c|}{45 DAP } & & \\
\hline & FP & TP & FP & TP & FP & TP & FP & TP \\
\hline Jhum 1 & 27.3 & 26.8 & 31.5 & 30.3 & 32.5 & 31.6 & 21.5 & 25.7 \\
\hline Jhum 2 & 27.6 & 26.5 & 31.9 & 29.9 & 32.1 & 31.9 & 22.8 & 31.5 \\
\hline Jhum 3 & 26.0 & 25.2 & 32.7 & 31.3 & 32.8 & 31.6 & 22.2 & 29.6 \\
\hline Mean & 27.0 & 26.2 & 32.3 & 30.3 & 32.5 & 31.7 & 22.2 & 28.9 \\
\hline
\end{tabular}

Table 2: Effect of paddy straw mulching on yield and economics of colocasia

\begin{tabular}{lllllllll}
\hline \multirow{2}{*}{ Location } & \multicolumn{2}{c}{ Yield $\left(\mathbf{k g ~ h a}^{-1}\right)$} & \multicolumn{2}{c}{ Gross income (₹) } & \multicolumn{2}{c}{ Net income (₹) } & B:C ratio \\
\cline { 2 - 9 } & FP & TP & FP & TP & FP & TP & FP & TP \\
\hline Jhum 1 & 2256 & 3080 & 1,12800 & 1,54000 & 62,300 & 1,03500 & 2.23 & 3.05 \\
Jhum 2 & 2340 & 2892 & 1,17000 & 1,17000 & 66,500 & 94,100 & 2.32 & 2.86 \\
Jhum 3 & 2280 & 3120 & 1,14000 & $1,56,000$ & 63,500 & 1,05500 & 2.26 & 3.09 \\
\hline Mean & 2292 & 3030 & 1,14600 & $1,51,533$ & 64,100 & 1,01033 & 2.27 & 3.00 \\
\hline
\end{tabular}

Table 3: Effect of paddy straw mulching on soil fertility status of colocasia crop after harvest

\begin{tabular}{lllllll}
\hline \multirow{2}{*}{ Location } & \multicolumn{2}{c}{ Available N (Kg ha-1) } & \multicolumn{2}{c}{ Available P (Kg ha-1) } & \multicolumn{2}{c}{ Available K (Kg ha $\left.\mathbf{~}^{-1}\right)$} \\
\cline { 2 - 7 } & FP & TP & FP & TP & FP & TP \\
\hline Jhum 1 & 276.30 & 299.10 & 20.21 & 27.67 & 161.70 & 224.23 \\
Jhum 2 & 280.12 & 311.22 & 20.98 & 27.97 & 162.78 & 218.14 \\
Jhum 3 & 284.23 & 329.34 & 21.67 & 28.45 & 185.98 & 245.56 \\
\hline Mean & 280.22 & 313.22 & 20.95 & 28.03 & 170.15 & 229.31 \\
\hline
\end{tabular}

${ }^{*} D A P-$ Days after planting; ${ }^{*} F P-$ Farmers practice; ${ }^{*} T P-$ Trial plots.

improved (Ji et al. 2001). About 34-50 \% reduction in soil water evaporation can be achieved through mulching with crop residue (Hatfield et al. 2001).

The mean yield, net income, and B:C ratio per hectare from the trial plots in the jhum fields were found to be higher with the use of paddy straw as mulching and fym in colocasia (Table 2). Its mean yield, net income, and B:C ratio were $3030 \mathrm{~kg} \mathrm{ha}^{-1}$, ₹ 101,033, and 3.00 over farmers practice of $2292 \mathrm{~kg}$ ha $^{-1}$, ₹ 64,100 , and 2.27. This increased yield may be due to the decay of organic mulch adding up soil nutrients, leading to its nutrient availability in the long run (Larentzaki et al. 2008). Ram et al. (2013) also reported an increase in the grain yield of wheat due to straw mulch. A similar observation was also reported in potatoes where yield was $24.04 \%$ higher in mulch conditions which might be due to sufficient moisture in the initial growth stage (Begum et al. 2014). Application of straw mulch in wheat which receives five irrigations, gives the highest net return (Brahma et al. 2007). Use of rice straw@10 t ha ${ }^{-1}$ in rabi-summer tomato found to increase the fruit yield, net income, and B: C ratio and at the same time control weeds and conserve soil moisture (Pandey et al. 2012).

The soil fertility status in the trial plots was also improved. The mean available nitrogen, phosphorus, and potassium were 313.22, 28.03, and $229.31 \mathrm{~kg} \mathrm{ha}^{-1}$ as compared to farmer's practice i.e. 280.22, 20.95, and $133.49 \mathrm{~kg} \mathrm{ha}^{-1}$ (Table 3). Khan et al. (2002) also reported an increase in soil available nitrogen, phosphorus and potassium due to paddy straw mulching in soil. Application of paddy straw mulch in rape seed-green gram-rice cropping system also increased the N, P, K availability in the soil (Mitra and Mandal 2012). The soil fertility is also improved through mulching over some time due to nutrient cycling through earthworm activity in the soil (Kader et al. 2017 and Qin et al. 2015). 


\section{CONCLUSION}

From the trials conducted in jhum fields of Lumami village under Zunheboto district of Nagaland, application of paddy straw @ $12 \mathrm{t} \mathrm{ha}^{-1}$ at $3 \mathrm{~cm}$ thickness and FYM@ $10 \mathrm{t} \mathrm{ha}^{-1}$ in colocasia crop have shown to decrease the soil temperature and increase the soil moisture in the jhum fields. The yield, net income, B:C ratio, and soil fertility status were also found to increase from the trials compared to farmers' practice. Thus, from the on-farm trials conducted under rainfed conditions, it was shown that the use of Paddy Straw Mulching and FYM in Colocasia crop in the jhum fields can could help to improve moisture conservation regulate the soil temperature, enhanced soil fertility over some time. Thereby increasing productivity and also enhanced income generation for livelihood.

\section{REFERENCES}

Anonymous. 2018. Statistical Handbook of Nagaland. Directorate of Economics \& Statistics. Available nitrogen in soils. Current Science, 25: 259-260.

Begum, M. and Saikia, M. 2014. Effect of Irrigation and Mulching on Growth and Yield Attributes of Potato. Agric. Sci. Digest., 34(1): $76-78$.

Brahma, R., Janawade, A.D. and Palled, Y.B. 2007. Effect of Irrigation Schedules, Mulch and Antitranspirant on Growth, Yield and Economics of Wheat (cv. DWD-I006). Karnataka, J. Agric. Sci., 20(1): 6 - 9.

Bray, R.H. and Kurtz, L.T. 1945. Determination of total, organic, and available forms of phosphorus in soils. Soil Sci., 59: 39-45.

Buragohain, J., Angami, T., Choudhary, B.U., Singh, P., Bhatt, B.P., Thirugnanavel, A. and Deka, B.C. 2013. Quality Evaluation of Indigenous Taro (Colocasia esculenta L.) Cultivars of Nagaland. Indian J. Hill Farm, 26(2): 16-20.

Chakraborty, D., Nagarajan, S., Aggarwal, P., Gupta, V. K., Tomar, R.K, Garg, R.N., Sahoo, R.N., Sarkar, A., Chopra, U.K., Sarma, K.S.S. and Kalra, N. 2008. Effect of mulching on soil and plant water status, and the growth and yield of wheat (Triticum aestivum L.) in a semi-arid environment. Agric. Water Manag., 95: 1323-1334.

Hatfield, J.L., Sauer, T.J. and Prueger, J.H. 2001. "Managing soils to achieve greater water use efficiency," Agron. J. 93(2): 271-280.

Jackson, M.L. 1967. "Soil chemical analysis" Prentice Hall of India Pvt. Ltd., New Delhi, pp. 498.

Ji, S. and Unger, P.W. 2001. "Soil water accumulation under different precipitation, potential evaporation, and straw mulch conditions," Soil Sci. Soc. America J., 65(2): 442-448.

Kader, M.A., Nakamura, K., Senge, M., Mojid, M.A. and Kawashima, S. 2019. Numerical simulation of water- and heat-flow regimes of mulched soil in rain-fed soybean field in central Japan. Soil Tillage Res., 191: 142-155.

Kader, M.A., Senge, M., Mojid., M.A. and Ito, K. 2017. Recent advances in mulching materials and methods for modifying soil environment. Soil Tillage Res., 168: 155-166.

Khan, A.R., Singh, S.S. and Nanda, P. 2002. Effect of organic mulching on physico-chemical properties of soil. The Abdus Salam International Centre For Theoretical Physics.

Kumar, P., Kumar, S. and Joshi, L. 2014. The Extent and Management of Crop Stubble. Springer Briefs in Environmental Science.

Larentzaki, E., Plate, J., Nault, B.A. and Shelton, A.M. 2008. Impact of straw mulch on populations of onion thrips (Thysanoptera: Thripidae) in onion. J. Econ. Entomol., 101: 1317-1324.

Mezhii, T.L., Changkija, S., Pattanayak, A., Chaturvedi, H.P., Devi, S.V. and Kole, P.R. 2017. Genetic Characterization of Locally Cultivated Taro Germplasm from Eleven District of Nagaland, India. Int. J. Curr. Microbiol. App. Sci., 6(8): 3338-3348.

Mitra, B. and Mandal, B. 2012. Effect of nutrient management and straw mulching on crop yield, uptake and soil fertility in rapeseed (Brassica campestris)-greengram (Vigna radiata)rice (Oryza sativa) cropping system under gangetic plains of india. Arch. Agron. Soil Sci., 58: 213-222.

Miyasaka, S., Hollyer, J. and Kodan, L.S. 2001. Mulch and compost effects on yield and corm rots of taro. Field Crops Res., 71(2): 101-112.

Pandey, V.K. and Mishra, A.C. 2012. Effect of Mulches on Soil Moisture and Fruit Yield in Summer Tomato (LM-10390). ISAE., 36(1).

Qin, W., Hu, C. and Oenema, O. 2015. Soil mulching significantly enhances yields and water and nitrogen use efficiencies of maize and wheat: a meta-analysis. Sci. Rep., 5: 16210.

Ram, H., Dadhwal, V., Vashist, K.K. and Kaur, H. 2013. Grain yield and water use efficiency of wheat in relation to irrigation levels and rice straw mulching in north west india. Agric. Water Manag., 128: 92-101.

Rashmi, D.R., Raghu, N., Gopenath, T.S., Pradeep, P., Bakthavatchalam, P., Karthikeyan, M., Gnanasekaran, A., Ranjith, M.S., Chandrashekrappa, G.K. and Basalingappa, K.M. 2018. Taro (Colocasia esculenta): An overview. J. Med. Plant Stud., 6(4): 156-161.

Subbiah B.V. and Asija G.L. 1956. A rapid procedure for estimation of available nitrogen in soils. Curr. Sci., 25: 259-260.

Suminarti, N.E., Patmawati, B., Pamungkas, A.R., Fajriani, S. and Fajrin, A.N. 2021. Effect of Size and Thickness of Mulch on Soil Temperature, Soil Humidity, Growth and Yield of Red Beetroot (Beta vulgaris L.) In Jatikerto Dry Land, Indonesia. Asian J. Plant Sci., 20: 33-43.

Temesgen, M. and Ratta, N. 2015. Nutritional potential, Health and Food Security Benefits of Taro Colocasia esculenta (L.): A Review. The Open Food Sci. J. 
Yang, Y.J., Dungan, R.S., Ibekwe, A.M., Solano, C.V., Crohn, D. M. and Crowley, D.E. 2003. "Effect of organic mulches on soil bacterial communities one year after application," Biol. Fertil. Soils, 38(5): 273-281.
Under Gangetic plains of India. Archives in Agronomy and Soil Science, 58: 213-222. 
